\title{
Sciendo
}

HOLISTICA Vol 10, Issue 2, 2019, pp. 83-94

\section{Antecedent and impact of procrastination on public sector}

\author{
Astuti, SIH DARMI, \\ Dian Nuswantoro University, Jalan Nakula I, No. 5-11 Semarang, Jawa Tengah, Indonesia, \\ astuti_sda@dsn.dinus.ac.id \\ Ingsih, KUSNI, \\ Dian Nuswantoro University, Jalan Nakula I, No. 5-11 Semarang, Jawa Tengah, Indonesia, \\ kusni.ingsih@dsn.dinus.ac.id
}

\begin{abstract}
The purpose of this study is to create a model of the procrastination on Public Works Office of Semarang City, Central Java. The increasing need for excellent service in the field of building and city planning, is increasingly increasing the workload for employees. The large number of community complaints about old problems and the difficulty of licensing and information and developer problems are important factors in performance appraisal. Factors that cause the length of processing of permits include lack of professionalism of civil servants in carrying out tasks and tend to like to postpone work. Based on the complaint, it is necessary to analyze what causes procrastination and how it impacts the agency. The population in this study were civil servants, with a sample of 111 people. Data obtained by survey method using a questionnaire. The analytical tool used is multiple linear regression analysis. The study found that workload and educational level had an impact on procrastination. Procrastination affects stress and employee performance. Workload is the strongest influence affecting procrastination, which has a direct impact on employee performance. While stress does not mediate the relationship of procrastination on employee performance.
\end{abstract}

Keywords: educational level; workload; procrastination; stress; employee performance

JEL Classification: M10, M12

\section{Introduction}

One measure of the success of the government is in carrying out its duties as a public servant. However, in its implementation, there are still many public complaints on the dissatisfaction to public services. The efforts to improve their services, in reality, have not been carried out by the government to the fullest either. One of the public services is the Public Works Office. This agency is in charge of administering government affairs and public services in the fields of spatial planning, building utilization and arrangement, construction technology 
and services, housing and settlements, and funeral. In its mission to improve service excellence in the field of building and city planning, the licensing and information are still complained by the public and developers, particularly regarding the length and difficulty of dealing with permits. The factors that cause the long duration of processing permits include the lack of the civil servant's professionalism in carrying out their tasks that tend to delay their works. Based on the complaints, the government is required to always fix the internal problems that disrupt the completion of tasks which will have an impact on the slow arrangement of building permits in the agency.

Procrastination is a delay in the work done by individuals, both to start a job and to complete a job (Metin, U.B., et al., 2016). Procrastination is often the cause of the non-fulfillment of targets that have been determined by the company, as well as for government agencies that are the cause of the length of completion of tasks that have an impact on the emergence of public complaints. This certainly greatly affects the effectiveness of work and employees performance. Every individual is required to always be disciplined and timely in work and in the completion of their duties. The leader in this situation must be able to fix and evaluate what factors cause procrastination.

One factor that causes procrastination is workload. Workload refers to the concentration or number of assignments and tasks, which are the responsibility of the employees at work (Ali, W.U., et al., 2014). The workload which is too heavy will interfere with the work process. Heavy workloads may cause physical and spastic fatigues, and the burden makes individuals more likely to do other activities considered more enjoyable and entertaining. Therefore, it is suspected that too heavy workload will affect individuals in the completion of their duties and tend to do work procrastination. The employee's educational level will also affect procrastination. The employees with higher education tend to be more able to manage their time and workload, but it is on the contrary with those with low educational level (Averill, 2000).

Procrastination is largely related to lower performance and higher stress (Steel, 2007; Van Eerde, 2003). Employees who exhibit a high level of procrastination often spend their working hours on activities not related to work. Therefore, to complete their daily tasks, it may take longer to work (so that the concentration level becomes lower and more fatigued) or may even rush to carry out their duties (so that it might lead to errors). As a result, it creates procrastination behavior, which results in lower performance results (Metin, U.B., et al., 2018). The organization must also provide counseling for employees to learn stress management techniques to overcome stress problems so that high 
performance can be achieved (Ali, W.U., et al., 2014). In other hand, the study of Gharib, M.N, et al. (2016) found that stress in ambiguity does not affect employee performance. The purpose of this study is to examine the conceptual model of procrastination on employee performance through empirical testing. Based on the phenomenon above and the findings of different studies, the authors are interested in examining this topic.

\section{Literature review}

\subsection{Educational level and procrastination}

The level of education is one of the factors causing procrastination. The ones with undergraduate education have better insight, ways of thinking, and behavior or self-control than those with non-graduate education. Averill (2000) mentions that self-control as personal control is an ability to control one's self in terms of behavior, cognitive, and decision controls.

Therefore, a person with undergraduate education is expected to be able to control himself/herself so that he/she can complete the task well without delaying works. A new model of agent-based procrastination integrates thinking from economic models about the dynamics of procrastination with psychological concepts that can help explain behavior at the individual level. One psychological factor for workers is the number of tasks that become a workload, i.e.: the structure of the task, delaying the task, and the reluctance of the task (Procee, et al., 2014). Based on several previous research findings, hypothesis 1 is compiled as follows:

H1: Educational level has a negative impact on procrastination

\subsection{Workload and procrastination}

Too heavy workloads will interfere with the work process. Heavy workload may cause physical exhaustion and psychological fatigue, and the burden experienced makes individuals more likely do other activities considered more enjoyable and entertaining. Based on this condition, it often causes too heavy workload that will affect individuals in the completion of their duties and tend to do work procrastination. The study conducted by Procee, et al. (2014) in the conceptual model shows the factors that influence procrastination. These factors are divided into different groups: related tasks, related personalities and other factors such as ego depletion, moods, temptations and coping strategies. Factors 
related to the task are task aversiveness, task delay, self-confidence incompetence, and task structure.

The study found that the task factor group especially task aversiveness was the dominant factor influencing procrastination. Workload will increase when there are illegitimate tasks that represent aspects of job design and influence decisions about tasks (Semmer, N.K., et al., 2015). This research was in line with the results of the research by DeArmond, S, et al. (2014) which concluded that workload has a positive impact on procrastination. Based on the above findings, hypothesis 2 was proposed as follows:

H2: Workload has a positive impact on procrastination

\subsection{Procrastination and stress}

Procrastination is often associated with increased work stress. Therefore, it would rather to start something delayed due to delays even though actually, when it is a habit of dealing with such pleasant work, it will probably be the real cause of stress (Beheshtifar, M., Moghadam, M.N., \& Hossenifar, H., 2014). Likewise, the study of Glick and Orsillo (2015) also concluded that even if students pursue recreational activities as a measure of stress reduction, this procrastination can lead to higher stress levels.

Procrastination considers the behavior of self-handicapping which leads to wasted time and increased stress. Besides, procrastination can also have different effects on the effectiveness of organizations and individuals. This is very important for managers to identify the causes and reasons for procrastination and try to overcome them (Beheshtifar, M., Hossenifar, H., \& Moghadam, M.N., 2011). Although there is still little research on procrastination and stress related to work in organizations, Tice and Baumeister (1997) confirm this relationship to students.

Their study found that students who have high procrastination will experience high stress. Based on several previous research findings, hypothesis 3 is compiled as follows:

H3: Procrastination has a positive impact on stress

\subsection{Procrastination and employee performance}

The study of Chu, C. and Choi (2005) also show that procrastination is a behavior that can lead to inability to save time and low performance. An employee who likes delaying work tends to create the work that has no value at all (Nguyen, 
B., et al., 2013). The employees who show a high level of procrastination will spend their time in working hours for activities not related to work. Therefore, to complete their daily tasks, they may work longer hours (due to lower levels of concentration and more fatigue) or may be in a hurry to do their assignments (which might lead to errors).

As a result, by being involved in procrastination behavior, employees can display lower performance. A chronic procrastinator is less likely to be employed (Barrick, et al., 2013). The other study conducted by Schultz, L.A. \& Sharp, J.H. (2017) found that there was a relationship between procrastination and performance, and the factors such as online education may also influence students' tendency to procrastinate.

Another study found that procrastination which considers self-injury behavior will lead to poor performance. Procrastination can also have different effects on the effectiveness of organizations and individuals, so it is very important for managers to identify various causes and reasons to overcome them (Beheshtifar, M., Hossenifar, H., \& Moghadam, M.N., 2011). There is other empirical evidence about the relationship between procrastination and decreased performance (Steel, 2007). Conceptually, procrastination is closely related to consciousness, which consistently changes with performance. Replace, people who like to delay work are worse in terms of what they achieve. Based on several previous research findings, hypothesis 4 is compiled as follows:

H4: Procrastination has a negative impact on employee performance

\subsection{Stress and employee performance}

The study results of Ahmed, A. and Ramzan, M. (2013) found that there is a negative correlation between work stress and performance and shows that work stress negatively and significantly reduces individual performance. Rose (2003) in his study found that stress in the work environment would reduce the intention of employees to work better at work. In addition, increasing the level of stress that employees think will also have an impact on demoralizing and their tendency to work well will also decrease. The other study that supports this relationship was the research conducted by Ali, W.U., et al. (2014). The employees, who face stress in their work, frequently cannot focus on their works and face difficulties in performing tasks (Khalid, A., et al., 2012).

Likewise the work stress model offered by Dawson, K.M, et al. (2016) which is as a demand, which is divided into two categories, namely obstacles and 
challenges, will increasingly have an impact on the achievement of employee performance. Based on the above findings, the hypothesis 5 was proposed as follows:

H5: Stress has a negative impact on employee performance

\section{Method}

The population in this study were all employees (116 people) of the Public Works Office of Semarang City, but the respondents were only 111 people, consisting of 82 men (73.87\%) and 29 women (26.13\%). The oldest age of the respondents was $30-40$ years $(36.9 \%)$, with most of them having high school education that accounted for 58 people (52.3\%).

The variable of procrastination used the measurements of Knaus (2010) with 6 items. The level of education was measured using three items of Tirtarahardja (2005), and the stress used 11 items of Robbins (2001). Then the performance was measured using five items of Koopmans, et al. (2012). The instrument testing for validity used factor analysis, and all items were proven to be valid. Meanwhile, the reliability test used Cronbach alpha which resulted in the value higher than 0.9. The data analysis in this study uses multiple linear regression.

\section{Results}

The results of the data analysis on means, standard deviation, reliability, and correlations in this study can be summarized in Table 1 as follows:

Table 1. Means, standard deviation, reliability, and correlations

\begin{tabular}{lccccccc}
\hline Variables & Means & SD & EL & W & $\mathbf{P}$ & S & EP \\
\hline EL & 4.405 & 0.823 & $\mathbf{( 0 . 9 1 5 )}$ & & & & \\
W & 5.982 & 0.976 & $0.017^{*}$ & $\mathbf{( 0 . 9 5 2 )}$ & & & \\
P & 6.032 & 0.754 & $-0.221^{* *}$ & $0.460^{* *}$ & $\mathbf{( 0 . 9 4 4 )}$ & & \\
S & 5.898 & 0.699 & $-0.102^{* *}$ & $0.326^{* *}$ & $0,474^{* *}$ & $\mathbf{( 0 . 9 4 6 )}$ & \\
EP & 5.903 & 0.77 & $0.104^{* *}$ & $0.362^{* *}$ & $-0.345^{* *}$ & $-0.246^{* *}$ & $\mathbf{( 0 . 9 0 5 )}$ \\
\hline
\end{tabular}

Source: Author, 2018

The value of alpha Cronbach is on the main of diagonal

${ }^{* *}$ Correlation is significant at the 0.01 level.

*Correlation is significant at the 0.05 level.

EL: Educational Level

W: Workload

P: Procrastination

S: Stress

EP: Employee Performance 
The description results of the data of the respondents show relatively good means and standard deviation. Likewise, for the instrument reliability test shows a high value; five variables show the alpha value higher than 0.9 . The results of the correlation analysis on the relationship between the variables show relatively low values, and it means that there is no multicollinearity.

Meanwhile, the results of the multiple linear regression analysis in this study can be summarized in Table 2 as follows:

Table 2. Regression analysis

\begin{tabular}{cllcc}
\hline Models & \multicolumn{1}{c}{ Dependent } & \multicolumn{1}{c}{ Independent } & Beta & Sign \\
\hline 1 & Procrastination & Educational Level & -0.211 & 0.007 \\
& & Workload & 0.556 & 0.000 \\
& & & & \\
& Adj $R^{2}: 0.346$ & & & 0.000 \\
2 & F: 30.073 & Procrastination & 0.574 & 0.000 \\
& Stress & & & \\
& Adj $R^{2}: 0.324$ & & & 0.000 \\
3 & F: 53.694 & Stress & 0.246 & 0.009 \\
& Employee Performance & Procrastination & -0.345 & 0.000 \\
& Adj $R^{2}: 0.111$ & & & \\
& F: 14.693 & & & 0.000 \\
\hline
\end{tabular}

Source: Author, 2018

The results of the multiple linear regression analysis for the three models provide a relatively poor model fit because the adjusted $\mathrm{R} 2$ test is relatively low in spite of relatively high F-test results with a significance value lower than 0.05 . The testing of the five proposed hypotheses obtained results that all proposed hypotheses were supported and presented in Table 3 below:

Table 3. Hypothesis testing

\begin{tabular}{|c|c|c|c|}
\hline Hypothesis & & Significance & Decision \\
\hline 1 & $\begin{array}{l}\text { Educational level has a negative } \\
\text { impact on procrastination }\end{array}$ & 0.007 & Supported \\
\hline 2 & $\begin{array}{l}\text { Workload has a positive impact on } \\
\text { procrastination }\end{array}$ & 0.000 & Supported \\
\hline 3 & $\begin{array}{l}\text { Procrastination has a positive impact } \\
\text { on stress }\end{array}$ & 0.000 & Supported \\
\hline 4 & $\begin{array}{l}\text { Procrastination has a negative impact } \\
\text { on employee performance }\end{array}$ & 0.000 & Supported \\
\hline 5 & $\begin{array}{l}\text { Stress has a negative impact on } \\
\text { employee performance }\end{array}$ & 0.009 & Supported \\
\hline
\end{tabular}

Source: Author, 2018 
Table 2 shows that the results of the regression analysis of Model 1 show that the level of education has a negative influence on procrastination with a regression value of -0.211 in a negative direction and a significant value of 0.007 which is less than $5 \%$. It means that hypothesis 1 is supported/accepted. Hypothesis 2 which tested the impact of workload on Procrastination results in a beta value of 0.556 and a significant value of 0.000 which is less than $5 \%$.

It can be concluded that the workload has a positive impact on procrastination, so $\mathrm{H} 2$ is accepted. The results of the regression analysis of model 2 show the impact of procrastination on work stress with a beta value of 0.574 and a significant value of 0.000 which is less than $5 \%$. It can be concluded that procrastination has a positive impact on stress, so H3 is accepted.

The results of the regression analysis of model 3 show that Procrastination has a beta value of -0.345 and a significant value of 0.000 which is less than $5 \%$. It can be concluded that procrastination has a negative impact on employee performance, so $\mathrm{H} 4$ is accepted.

The results of the regression analysis of model 3 show that job stress has an impact on employee performance with a beta value of -0.246 and a significant value of 0.009 which is less than $5 \%$. It can be concluded that stress has a negative impact on employee performance, so $\mathrm{H} 5$ is supported.

\section{Discussion, and Conclusions}

Hypothesis 1 shows that the level of education has a negative influence on procrastination. It means that a low level of education will increase procrastination. It can be concluded that the level of education has a negative influence on procrastination, so $\mathrm{H} 1$ is accepted.

Surprisingly that there is a high procrastination. This is caused by low education levels. This is an irony, because employees in the public sector should have a high level of education in order to be able to provide good service to the community now. The level of education is one of the factors causing procrastination. The staffs of the Spatial Planning Agency with the educational level dominated by high school qualifications (52.3\%) were highly vulnerable to procrastination. Meanwhile, $36.9 \%$ of them were bachelors and only $8.1 \%$ of them were postgraduates.

Someone with a bachelor degree has better insight, behavior control or self-control, and ways of thinking than those with non-graduate education. Averill (2000) mentions that self-control as a personal control is an ability to control one's 
self in terms of behavior, cognitive, and decision controls. Therefore, a person with bachelor degree is expected to be able to control himself/herself so that he/she can complete the tasks well and does not delay his/her works. This research supports the results of studies conducted by Procee, et al. (2014) which concluded that the level of education has a negative influence on procrastination.

Hypothesis 2 is accepted, so it can be concluded that the workload has a positive impact on procrastination. Too heavy workload will interfere with work process. Heavy workload may cause physical exhaustion and psychological fatigue, and the burden experienced makes individuals more likely do other activities considered more enjoyable and entertaining.

Therefore, it is suspected that the workload that is too heavy will affect individuals in the completion of their duties and tend to do work procrastination. It seems that time management will be an alternative solution in the face of procrastination.

Managing time effectively can help employees feel in control of their workload, increase their productivity, and increase their confidence. As a result, they will feel less likely to delay and be able to enjoy a healthy balance between completing their tasks and responsibilities with other activities. This research is in line with the results of the research by DeArmond, S, et al. (2014) which concluded that workload has a positive impact on procrastination.

The testing results of hypothesis 3 were accepted. It means that the higher the procrastination, the higher the level of job stress felt by the employees. Procrastination in the form of slowness in working on tasks and difficulties in adjusting to the plan will have an impact on high-stress levels. The stress occurred can be the stress of individuals and organizations. Individual stress is reflected in decreasing interpersonal relationships and work performance and causes anxiety and tension.

This study supported the research conducted by Beheshtifar, M., Moghadam, M.N., and Hossenifar, H. (2014). Likewise, the study of Glick and Orsillo (2015) found that procrastination may lead to higher stress levels.

The testing results of hypothesis 4 were accepted, and it shows that Procrastination has an impact on employee performance. The lack of the fulfillment of the targeted number/quantity of works in one period and the low cooperation with colleagues and work teams were the forms of low performance as a result of procrastination. 
Another fact is that, it seems that someone who has a high level of energy, mental endurance, and enthusiasm, and concentration, will not spend much time on activities that are not related to work during their working hours.

This means that procrastination and performance are negatively related. Therefore, it is very reasonable that often they will spend excessive time on personal activities when actually working (such as reading blogs, engaging in gossip, Instagram, games, WhatsApp and short messages/SMS, etc.). These conditions can negatively affect performance, either by reducing the quality or number of works committed.

This study supported previous studies conducted by Nguyen, B., et al. (2013). Likewise, the studies found that chronic delayers tend to be less employed (Barrick, M.R., et al., 2013) The other study conducted by Schultz, L.A. and Sharp, J.H. (2017) also found that there is a relationship procrastination and employee performance.

The results of the regression analysis of tested hypothesis 5 show that work stress has a negative influence on employee performance. It means that employees with high job stress have an impact on low performance. This study supported the previous study conducted by Ahmed, A. and Ramzan, M. (2013) who found that there is a negative relationship between job stress and job performance and shows that job stress negatively and significantly reduces individual performance. Likewise, the study of Rose (2003) found a negative impact of job stress on employee performance.

The other study conducted by Ali, W.U., et al. (2014) also supported this relationship. The other similar studies by Khalid, A., et al., (2012) found similar results that the employees who face stress in their works frequently cannot focus on their works and face difficulties in carrying out tasks.

This research have several finding, that the antecedents and the impacts of procrastination at Public Works Office Semarang City can be explained as follows:

1. Workload and educational level were the factors that influenced procrastination.

2. Workload as the strongest factor in positively influencing procrastination, which in turn had an impact on employee performance.

3. Education level plays a role in increasing procrastination, which in turn affected employee performance.

4. The impacts of procrastination were stress and employee performance. 


\section{References}

[1] Ahmed, A., \& Ramzan, M. (2013). Effects of Job Stress on Employees Job Performance A Study on Banking Sector of Pakistan. IOSR Journal of Business and Management (IOSR-JBM), pp. 6168.

[2] Ali, W.U., et al. (2014). Impact of Stress on Job Performance: An Empirical Study of The Employees of Private Sector Universities of Karachi, Pakistan. Research Journal of Management Sciences, pp. 14-17.

[3] Barrick, M.R., Mount, M.K., \& Li, N. (2013). The Theory of Purposeful Work Behavior: The Role of Personality, Higher Order Goals, and Job Characteristics. Academy of Management Review, pp. 132-153.

[4] Beheshtifar, M., Hossenifar, H., \& Moghadam, M.N. (2011). Effect Procrastination on WorkRelated Stress. European Journal of Economics, Finance and Administrative Sciences.

[5] Beheshtifar, M., Moghadam, M.N., \& Hossenifar, H. (2014). The Survey of Relationship between Employees' Procrastination and Their Job Stress. Applied Mathematics in Engineering, Management and Technology, pp. 9-17.

[6] Chu, C., \& Choi, J.N. (2005). Rethinking Procrastination: Positive Effects of "Active" Procrastination in Behavior on Attitudes and Performance. The Journal of Social Psychology, pp. 245-247.

[7] dan Baumeister, T. (1997). Longitudinal study of procrastination, performance, stress, and health: The cost and benefits of dawdling. Psychological Science, pp. 454.

[8] Dawson, K.M., O'brien, K.E., \& Beehr, T.A. (2016). The role of hindrance stressors in the job demand-control-support model of occupational stress: A proposed theory revision. Journal of Organizational Behavior, pp. 397-415.

[9] DeArmond, S, et al. (2014). Workload and Procrastination: The Roles of Psychological Detachment and Fatigue. International Journal of Stress Management, pp. 137-161.

[10] Gharib, M.N, et al. (2016). The Impact of Job Stress on Job Performance: A Case Study on Academic Staff at Dhofar University. International Journal of Economic Research, pp. 21-33.

[11] Glick, \& Orsillo. (2015). An Investigation of The Efficacy of Acceptance-based Behavioral Therapy for Academic Procrastination. Journal of Experimental Psychology: General, pp. 400409.

[12] Khalid, A., et al. (2012). Role of Supportive Leadership as a Moderator Between Job Stress and Job Performance. Information Management and Business Review, pp. 487-495.

[13] Koopmans, et al. (2012). Development of An Individual Work Performance Questionnaire. International Journal of Productivity and Performance Management, pp. 6-28.

[14] Metin, U.B., Peeters, M.C.W, \& Taris, T.W. (2016). Measuring Procrastination at Work and Its Associated Workplace Aspects. Personality and Individual Differences, pp. 254-263.

[15] Metin, U.B., Peeters, M.C.W, \& Taris, T.W. (2018). Correlates of Procrastination and Performance at Work: The Role of Having "Good Fit". Journal of Prevention \& Intervention in The Community, pp. 228-244.

[16] Nguyen, B., et al., (2013). Procrastination's Impact in The Workplace and The Workplace's Impact on Procrastination. International Journal of Selection and Assessment.

[17] Procee, et al. (2014). An Agent-Based Model of Procrastination. Prestigious Applications of Intelligent Systems Conference, pp. 747-752.

[18] Rose, M. (2003). Good Deal, Bad Deal? Job Satisfaction in Occupational. Work Employment Society, pp. 503. 
[19] Schultz, L.A., \& Sharp, J.H. (2017). Procrastination and Performance in Computer Information System Courses. Proceeding of the EDSIG Conference Austin, Texas, USA.

[20] Semmer, N.K., Jacobshagen, N., Meier, L.L., Elfering, A., Beehr, T.A., Kälin, W., \& Tschan, F. (2015). Illegitimate tasks as a source of work stress. Work \& Stress, pp. 32-56.

[21] Steel, P. (2007). The Nature of Procrastination: A Meta-analytic and Theoretical Review of Quintessential Self-Regulatory Failure. Psychological Bulletin, pp. 65-94.

[22] Van Eerde, W. (2003). A Meta-analytically Derived Nomological Network of Procrastination. Personality and Individual Differences, pp. 1401-1418. 